\title{
Comparative pharmacology of a new recombinant FSH expressed by a human cell line
}

\author{
Wolfgang Koechling 1,*, Daniel Plaksin'2, , Glenn E Croston ${ }^{3}$, Janni V Jeppesen 4 , \\ Kirsten T Macklon ${ }^{4}$ and Claus Yding Andersen ${ }^{4}$
}

${ }^{1}$ Ferring Pharmaceuticals A/S, Copenhagen, Denmark

${ }^{2}$ Bio-Technology General Israel Ltd, Ferring Pharmaceuticals, Kiryat Malachi, Israel

${ }^{3}$ Croston Consulting, San Diego, California, USA

${ }^{4}$ The Laboratory of Reproductive Biology, The Department of Fertility at The Juliane Marie Centre,

Rigshospitalet, Copenhagen University Hospital and The University of Copenhagen, Copenhagen, Denmark

*(W Koechling and D Plaksin contributed equally to this work)

Correspondence

should be addressed

to W Koechling

Email

wkg@ferring.com

\begin{abstract}
Recombinant FSH proteins are important therapeutic agents for the treatment of infertility, including follitropin alfa expressed in Chinese Hamster Ovary ( $\mathrm{CHO}$ ) cells and, more recently, follitropin delta expressed in the human cell line PER.C6. These recombinant FSH proteins have distinct glycosylation, and have distinct pharmacokinetic and pharmacodynamic profiles in women. Comparative experiments demonstrated that follitropin delta and follitropin alfa displayed the same in vitro potency at the human FSH receptor, but varied in their pharmacokinetics in mouse and rat. While follitropin delta clearance from serum depended in part on the hepatic asialoglycoprotein receptor (ASGPR), follitropin alfa clearance was unaffected by ASGPR inhibition in rat or genetic ablation in mice. The distinct properties of follitropin delta and follitropin alfa are likely to contribute to the differing pharmacokinetic and pharmacodynamic profiles observed in women and to influence their efficacy in therapeutic protocols for the treatment of infertility.
\end{abstract}

\author{
Key Words \\ - follicle-stimulating \\ hormone \\ - follitropin delta \\ - gonadotropin clearance \\ - recombinant FSH \\ - FSH glycosylation
}

\section{Introduction}

Follicle-stimulating hormone (FSH) released from the anterior pituitary in response to gonadotropin-releasing hormone $(\mathrm{GnRH})$ plays a central role in reproduction in women, driving the growth and maturation of ovarian follicles, and regulating ovarian steroidogenesis (1). In addition, exogenous FSH plays a central role in the treatment of infertility (2), including in vitro fertilization (IVF) or intracytoplasmic sperm injection (ICSI), with the GnRH antagonist protocol increasingly common due to safety and convenience (3). As a result, continued innovation in infertility therapy is likely to involve both novel FSH proteins and novel treatment protocols.
FSH is composed of two extensively glycosylated protein subunits, and to express recombinant FSH ( $\mathrm{rFSH}$ ) for therapeutic use, the genes encoding the human FSH subunits are introduced into a mammalian cell line from which FSH protein is secreted and purified (4). Early recombinant FSH proteins expressed in Chinese Hamster Ovary $(\mathrm{CHO})$ cells are termed follitropin alfa or follitropin beta $(4,5,6)$, and display distinct glycosylation compared to urinary-derived endogenous human FSH, occurring as a range of isoforms of varying acidity that are on average slightly less acidic in isoelectric focusing (7). Compared to human urinary FSH, CHO cell-derived rFSH lacks bisecting http://www.endocrineconnections.org
DOI: $10.1530 /$ EC-17-0067
() 2017 The authors Published by Bioscientifica Ltd

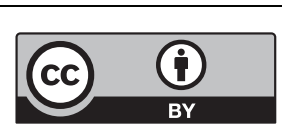

This work is licensed under a Creative Commons Attribution 4.0 International License. 
GlcNAc residues, has a lower percentage of alpha 1-6 fucose and lacks alpha 2,6-linked sialic acid, while urinary FSH contains both alpha 2,3- and alpha 2,6-linked sialic acid $(7,8,9)$.

Recently follitropin delta has been described (FE 999049), the first recombinant FSH protein in clinical development that is expressed in a human cell line (PER.C6), with individualized dosing optimized based on each patient's weight and anti-Mullerian hormone $(\mathrm{AMH})$ level $(10,11,12)$. In female volunteers, follitropin delta displayed distinct pharmacokinetics and pharmacodynamics, with higher exposure and lower serum clearance than follitropin alfa (13). Moreover, the outcome of this phase 1 study demonstrated that the bioactivity of follitropin delta in the rat SteelmanPohley assay compared to a reference standard did not directly predict proportional pharmacodynamic activity in women (13). These observations suggest that improved understanding of the distinct pharmacodynamics and pharmacokinetics of these recombinant FSH proteins will aid in their therapeutic application.

While follitropin alfa and follitropin delta have the same amino acid FSH sequence, they vary in their glycosylation (14). Follitropin delta has a higher proportion of tri- and tetra-sialylated glycans, with both alpha2,3- and alpha2,6-linked sialic acid, while follitropin alfa has only alpha2,3-linked sialic acid, in addition to other differences in glycosylation. More acidic isoforms of FSH with greater sialic acid modification and a lower isoelectric point are less potent in vitro at the human $\mathrm{FSH}$ receptor compared to more basic FSH isoforms, and also display lower serum clearance and longer circulating halflife $(15,16,17,18,19)$.

To examine how the distinct glycosylation of follitropin alfa and follitropin delta affects their pharmacological activity, the in vitro and in vivo bioactivity of both recombinant FSH preparations was directly compared. For this purpose, the binding affinities of follitropin delta and follitropin alfa at the human FSH receptor were determined, and their bioactivities were tested in a HEK-293 cell line stably expressing the human FSH receptor, and in human granulosa cells isolated during oocyte pick-up prior to IVF. The pharmacokinetic behavior of the two rFSH proteins was also analyzed in rodents, examining the role of the ASGP receptor in mouse and rat on $\mathrm{rFSH}$ clearance from circulation.

\section{Methods}

\section{Follitropin alfa and follitropin delta}

Follitropin alfa produced in $\mathrm{CHO}$ cells was obtained from the market (Gonal F, Merck Serono, Batches BA018199A, AU009535, AU003768, BAD 04143, PS-3577, Y02A9111), and diluted and tested as indicated in each experimental method. Follitropin delta samples produced in the human cell line PER.C6 were provided by Ferring Pharmaceuticals (Batches FSMB01/2, G16641, G11105, CE0041, 1178-160) and characterized and diluted for testing as indicated in each experimental procedure. The first international standard for recombinant FSH (NIBSC 92/642) was obtained from NIBSC (National Institute for Biological Standards and Control).

\section{Human FSH receptor binding}

The binding displacement assay for the human FSH receptor was performed utilizing [Propionyl- ${ }^{3} \mathrm{H}$ ] FSH as the radiolabel (Quotient Research, UK). Incubation Buffer and Stop Buffer was $10 \mathrm{mM}$ Tris, $25 \mathrm{mM} \mathrm{MgCl}_{2}, 0.5 \%$ BSA, $\mathrm{pH}$ 7.5. Follitropin delta used in these experiments had a protein concentration of $0.62 \mathrm{mg} / \mathrm{mL}$ and an assumed molecular weight of $33,000 \mathrm{~g} / \mathrm{mol}$. A sample of follitropin alfa with an assumed molecular weight of $31,000 \mathrm{~g} / \mathrm{mol}$, with $5.5 \mu \mathrm{g}$ or $75 \mathrm{IU}$ powder dissolved in $1.2 \mathrm{~mL}$ of the incubation buffer and the stock solution at $0.15 \mu \mathrm{M}$ was aliquoted and stocked at $-20^{\circ} \mathrm{C}$. For both compounds, all dilutions were performed in the incubation buffer.

To make membranes, a frozen pellet of HEK-293 cells expressing human FSH receptor (approximately 600 million cells) was suspended in buffer containing $50 \mathrm{mM}$ Tris- $\mathrm{HCl}, 5 \mathrm{mM}$ EDTA-Tris, $20 \mathrm{mM} \mathrm{NaCl}, 5 \mathrm{mM}$ $\mathrm{KCl}, 5 \mathrm{mM} \mathrm{MgCl}_{2}, 1.5 \mathrm{mM} \mathrm{CaCl}, 10 \mu \mathrm{g} / \mathrm{mL}$ trypsin inhibitor, $1 \mu \mathrm{g} / \mathrm{mL}$ leupeptin, $75 \mu \mathrm{g} / \mathrm{mL}$ PMSF, $\mathrm{pH}$ 7.4. After centrifugation at $50,000 \mathrm{~g}$ for $15 \mathrm{~min}\left(4^{\circ} \mathrm{C}\right)$, the pellet was suspended in the same buffer with the addition of $10 \%$ glycerol. The protein concentration was determined with the Bradford methodology and the aliquots was stored at $-80^{\circ} \mathrm{C}$.

To initiate binding, FSH receptor membranes containing $180 \mu \mathrm{g}$ protein were incubated one hour at $37^{\circ} \mathrm{C}$ with $0.4 \mathrm{nM}$ of [Propionyl- ${ }^{3} \mathrm{H}$ ] FSH and the indicated quantity of follitropin alfa or follitropin delta. Unifilter GF/B filters (Whatman, UK) were pre-soaked with $10 \mathrm{mM}$ Tris- $\mathrm{HCl}, 25 \mathrm{mM} \mathrm{MgCl}_{2}, 0.5 \% \mathrm{BSA}, \mathrm{pH}$ 7.5. Incubated http://www.endocrineconnections.org
DOI: 10.1530/EC-17-0067
() 2017 The authors Published by Bioscientifica Ltd

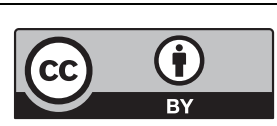

This work is licensed under a Creative Commons Attribution 4.0 International License. 
mixtures were filtered through pre-soaked filters using a Packard FilterMate Harvester, and washed 3-4 times using the same buffer. Filters were then dried, MICROSCINT 0 scintillation fluid (PerkinElmer) was added $(30 \mu \mathrm{L} /$ well) and scintillation counting was performed using a Packard Topcount NXT instrument ( 1 min per well).

$K_{\mathrm{i}}$ was estimated by the Cheng-Prusoff equation (20).

\section{In vitro bioactivity using a HEK-293 cell line expressing the human FSH receptor}

Human embryonic kidney 293 (HEK-293) cells stably transfected with the human FSH receptor (21) were thawed from frozen aliquots, and grown and passaged in DMEM with $4.5 \mathrm{~g} / \mathrm{L}$ D-glucose (Biological Industries, Israel) containing 5\% fetal bovine serum, heat inactivated (Biological Industries) and $2 \mathrm{mM}$ L-glutamine (Biological Industries). For assays, hFSH receptor expressing cells were incubated with the indicated concentrations of rFSH proteins for $90 \mathrm{~min}$. At the end of the incubation, cells were lysed and cAMP produced in response to $\mathrm{rFSH}$ stimulation quantitated using the DiscoveRx HitHunter cAMP XS + cAMP assay kit (DiscoveRx, Fremont, CA, USA), measuring luminescence using the TECAN Infinite F200 plate reader and reporting RLU. Data were analyzed using four-parameter curve-fitting (Graphpad Prism).

\section{In vitro bioactivity using fresh luteinized granulosa cells from IVF patients}

To determine the activity of $\mathrm{rFSH}$ proteins, human granulosa cells were collected from 13 women ages 26-39 years $(34.5 \pm 1.2$ years, mean \pm s.E.M.) undergoing IVF treatment at the University Hospital of Copenhagen, with approval of the project by the ethical committee of the municipalities of Copenhagen and Frederiksberg (H-32013-201). The studies in which $\mathrm{rFSH}$ proteins were compared utilized cells from eight of these patients. Women were either stimulated following a long agonist protocol or a standard antagonist protocol. In all cases, a bolus injection of hCG was used for final oocyte maturation $36 \mathrm{~h}$ prior to oocyte collection. Granulosa cells were collected in connection with aspiration of oocytes for IVF treatment. After oocytes were removed from the follicular aspirates, the granulosa cells from each patient were collected in a pool and purified using a lymphoprep gradient (Stemcell Technologies, Grenoble, France) where fluid was maintained in the upper layer, while red blood cells were collected in the pellet and the

http://www.endocrineconnections.org DOI: 10.1530/EC-17-0067

(C) 2017 The author Published by Bioscientifica Ltd granulosa cells were located in the intermediate layer. After aspiration of the granulosa cells layer, large clumps of cells were removed under a microscope and stored at $-80^{\circ} \mathrm{C}$ until used for DNA purification and detection of the 307/680 FSHR and the -29 FSHR polymorphism of the patient (22). A single cell suspension of granulosa cells was prepared from the smaller clumps of cells by the addition of the proteolytic enzyme mix Tryple (mainly trypsin) for up to $5 \mathrm{~min}$ or until the clumps became disintegrated. Proteases were inactivated by the addition of FBS, and the suspension was centrifuged $(400 \mathrm{~g} 10 \mathrm{~min})$ to pellet the granulosa cells. Granulosa cells were cultured in 4-well dishes (Nunc, Roskilde, Denmark) at $37^{\circ} \mathrm{C}$ with $6.5 \% \mathrm{O}_{2}$ in culture medium consisting of MEM Alpha medium (Gibco) supplemented with human serum albumin $10 \mathrm{mg} / \mathrm{mL}$ (CSL Behring, Lyngby, Denmark); $50 \mathrm{mg} / \mathrm{mL}$ FBS (Gibco); 2 mM GlutaMAX (Gibco), Insulin-Tranferrin-Selenium mix (Gibco); and Pen/strep (Gibco). The first $24 \mathrm{~h}$ cells were allowed to attach to the bottom in the presence of $50 \mathrm{mg} / \mathrm{mL}$ FBS after which the culture medium was changed. After $48 \mathrm{~h}$, cells were stimulated by $\mathrm{rFSH}$ for $24 \mathrm{~h}$. Thereafter the media was harvested, snap frozen and stored at $-80^{\circ} \mathrm{C}$ until thawed for hormone measurements. The cells attached to the bottom were washed in prewarmed PBS (Gibco) prior to being lysed. The granulosa cells were lysed with the lysis buffer purchased with the mRNA purification kit (see below), snap frozen and stored at $-80^{\circ} \mathrm{C}$ until RNA purification and qPCR.

Purification of mRNA was performed using Agilent Absolutely RNA nanoprep kit (Agilent Technologies). All steps were performed on ice, apart from the elution of isolated mRNA. First strand cDNA synthesis was performed using Applied Biosystems High Capacity cDNA reverse transcription kit (Applied Biosystems) with following temperature profiles: $25^{\circ} \mathrm{C}$ for $10 \mathrm{~min}, 37^{\circ} \mathrm{C}$ for $120 \mathrm{~min}$, $85^{\circ} \mathrm{C}$ in $5 \mathrm{~s}$ and $4^{\circ} \mathrm{C}$ until the synthesis was terminated. All first-strand cDNA syntheses were performed on a Thermal cycler (ThermoFisher Scientific Arktik thermal cycler block). TaqMan Universal PCR master mix (Applied Biosystems) and pre-designed TaqMan probes were tagged with a FAM-labeling (Applied Biosystems): Cyp19a1 (Hs00903412_m1), 3beta-HSD (Hs01084547_gH), INHA (HS00171410_m1) and GAPDH (Hs99999905_m1) as a housekeeping gene. qPCR reactions were performed in a total volume of $10 \mu \mathrm{L}$ consisting of a mixture of $0.5 \mu \mathrm{L}$ $20 \times$ TaqMan gene expression assay, $5.0 \mu \mathrm{L} 2 \times$ TaqMan gene expression master mix, $2.0 \mu \mathrm{L}$ cDNA and $2.5 \mu \mathrm{L}$ RNase free water for each single reaction. The qPCR plates (Roche Diagnostics) were centrifuged at $1000 \mathrm{~g}$ before

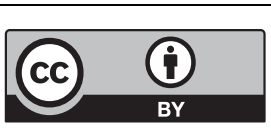

This work is licensed under a Creative Commons Attribution 4.0 International License. 
analysis using the LightCycler 480 (Roche) with the following program for 45 cycles; pre-incubation: $50^{\circ} \mathrm{C}$ for $2 \mathrm{~min}$, followed by $95^{\circ} \mathrm{C}$ for $10 \mathrm{~min}$, amplification at $95^{\circ} \mathrm{C}$ for $15 \mathrm{~s}$ and $60^{\circ} \mathrm{C}$ for $1 \mathrm{~min}$, followed by a quantification measurement, ending by cooling to $40^{\circ} \mathrm{C}$ in $30 \mathrm{~s}$. All samples were run in duplicates and normalized to the corresponding GAPDH gene expression value.

The calculation of the expression level of each individual gene was carried out according to the Comparative CT Method for relative quantification of gene expression (23). Concentrations of estradiol and progesterone were measured using commercially available ELISA kits (NovaTec Immundiagnostica, Germany). A PBS solution containing 1\% BSA was used for dilution of the culture media samples prior to measurements. Dilutions of 1:10 for estradiol and 1:500 of progesterone secured readings inside of the standard curve. All samples were run in duplicate, and the mean of the replicates was used. Inhibin A and inhibin B were measured using commercially available ELISA kits (AnshLabs, Webster, USA). Serum from post-menopausal women devoid of inhibin A and inhibin B was used to dilute samples.

\section{Steelman-Pohley assay}

Follitropin alfa was obtained from a freeze-dried vial stated by the manufacturer to contain $600 \mathrm{IU}$ of rFSH per and filled by mass to contain $44 \mu \mathrm{g}$ of FSH per mL. Follitropin delta was measured by size exclusion chromatography HPLC to contain $39 \mu \mathrm{g}$ of FSH per $\mathrm{mL}$ and $600 \mathrm{IU} / \mathrm{mL}$ in liquid formulation.

The Steelman-Pohley assay (24) was performed according to USP monograph for Menotropins and the Ph Eur monograph for Urofollitropin (USP Monograph: Mentotropins 4/30/08, PhEUR: Urofollitropin 01/2008/0958), with immature female Sprague-Dawley rats (Harlan, Jerusalem, Israel), 20-21 days old (35-45 g) having weights such that the difference between the heaviest and the lightest rat is not more than $10 \mathrm{~g}$. Animals were fed a standard diet and allowed free access to water, randomly distributing animals for the experiment with seven animals in each group.

Solution A used for the dilution of proteins for injection was $130 \mathrm{mM} \mathrm{NaCl}, 75 \mathrm{mM} \mathrm{Na}_{2} \mathrm{HPO}_{4}-2 \mathrm{H}_{2} \mathrm{O}, 0.1 \%$ BSA, pH 7.5. hCG was diluted to $700 \mathrm{IU} / \mathrm{mL}$ in Solution $\mathrm{B}$, which includes $130 \mathrm{mM} \mathrm{NaCl}, 75 \mathrm{mM} \mathrm{Na}_{2} \mathrm{HPO}_{4}-2 \mathrm{H}_{2} \mathrm{O}, 1 \%$ BSA, pH 7.5, and further diluted in Solution A to $70 \mathrm{IU} / \mathrm{mL}$, which was then used for the preparation of proteins and controls for injection.
For each rFSH protein, a $0.2 \mathrm{~mL}$ volume was injected once per day for three days at three dose levels subcutaneously in the dorsal area for each, according to established assay guidelines, with the injection also containing 14IU of hCG (Serono). The weight of each animal was recorded at the beginning and end of each experiment. Twenty-four hours after the last injection, animals were killed, and ovaries were removed and cleaned of extraneous tissues, blotted dry, and pairs of ovaries weighed.

\section{Specialized rat pharmacokinetics (ASF competition)}

Identical volumes $(0.5 \mathrm{~mL})$ and concentrations $(4 \mu \mathrm{g} / \mathrm{mL})$ of follitropin delta and follitropin alfa were injected IV into male Sprague-Dawley rats weighing 80-85 g (Harlan) in the presence and absence of asialofetuin (Sigma). Animals ( 2 per treatment group) were bled at specific time points $(0.25,1,2$ and $4 \mathrm{~h}$ post injection), and sera were tested for FSH concentration by ELISA in duplicates (DRG Instruments GmbH, Marburg, Germany). For the ELISA, $100 \mu \mathrm{L}$ of anti-FSH enzyme conjugate was added to samples, and plates were incubated for $30 \mathrm{~min}$ at room temperature. Contents of wells were removed and rinsed 5 times with water, inverting plates to dry. Substrate solution was added and incubated $5 \mathrm{~min}$ at room temperature before adding $50 \mu \mathrm{L}$ of stop solution, and absorbance was read at $450 \mathrm{nM}$. The anti-human FSH antibody used in the ELISA for the detection of recombinant human FSH proteins displayed no measureable interference from rat or mouse serum (data not shown). Results in the presence and absence of ASF were compared using a Student's $t$-test at $P<0.05$.

\section{Specialized mouse pharmacokinetics (Asgpr knockout model)}

Homozygous asialoglycoprotein receptor knockout (KO) mice (B6;129S7-Asgr2tm1Her/J) (25) were obtained from The Jackson Laboratory, and wild-type C57Bl/6J mice were obtained from Harlan Laboratories. Weight of the mice was from 22 to $24 \mathrm{~g}$. Follitropin alfa freeze-dried powder was reconstituted in the laboratory with dissolving solution supplied. Follitropin delta drug product was received in a solution form. Identical volumes $(0.5 \mathrm{~mL})$ and concentrations $(6 \mu \mathrm{g} / \mathrm{mL})$ of follitropin alfa and follitropin delta were injected subcutaneously (SC) into both male C57Bl/6J mice and male Asgpr knockout mice. Animals ( $n=3$ per treatment group) were bled at specific

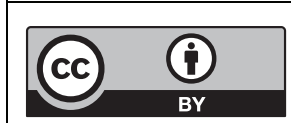

This work is licensed under a Creative Commons Attribution 4.0 International License. 
time points thereafter $(0.5,3,6,9$ and $24 \mathrm{~h}$ post dosing), and sera were tested for FSH concentration by ELISA in triplicates.

The mean serum concentrations of follitropin delta were normalized based on the ELISA concentration of the original injected vials compared to follitropin alfa. Serum FSH concentration vs time was plotted, and a classical trapezoidal rule was used to compute the area under the curve (AUC) by 'PK Solutions 2.0' software. The AUC value of FE follitropin delta is presented as a percent of the AUC value calculated for follitropin alfa. Results at each time point were compared between wild-type and Asgpr knockout animals using a Student's $t$-test with $P<0.05$ as the criteria for significance.

\section{Results}

\section{Human FSH receptor binding}

FSH receptor binding affinity was measured by displacement of radiolabeled $\mathrm{FSH}$ from the human FSH receptor. Propionyl- ${ }^{3} \mathrm{H}$ labeled FSH was used as the radiolabeled ligand in these studies, with membranes prepared from recombinant HEK 293 cells expressing the human FSH receptor. The $K_{d}$ value of [Propionyl- ${ }^{3} \mathrm{H}$ ] FSH in this assay was $0.2 \mathrm{nM}$ with a $B_{\max }$ of $28 \mathrm{fmol} /$ $\mathrm{mg}$ protein (data not shown). The average $\mathrm{IC}_{50}$ in three experiments for displacement of propionyl- ${ }^{3} \mathrm{H}$ FSH was virtually identical for the two rFSH proteins, $0.302 \mathrm{nM}$ for

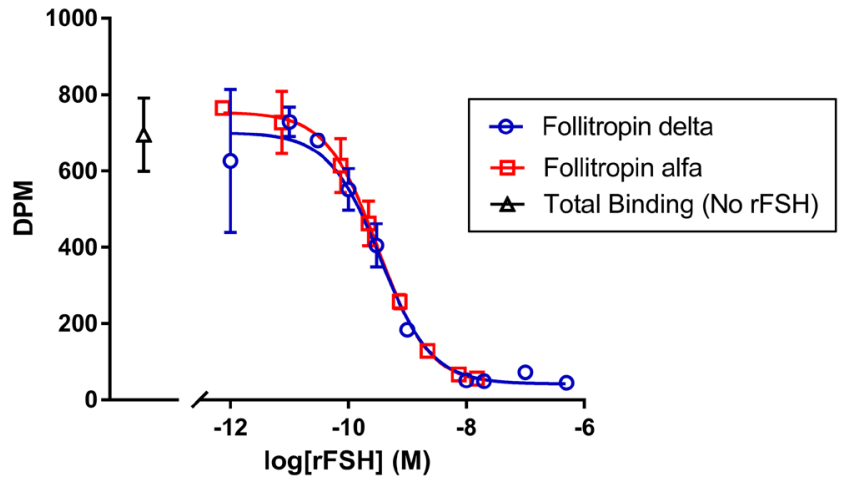

Figure 1

The displacement of radiolabeled propionyl- ${ }^{3} \mathrm{H}$ FSH from human FSH receptor was measured as a reduction in $\mathrm{dpm}$ bound across the indicated concentrations of follitropin delta (open circles, blue) and follitropin alfa (open squares, red), or total binding in the absence of unlabeled recombinant FSH protein (open triangle, black). Each concentration was tested in duplicate, with the mean and s.D. indicated. Data were fit using four-parameter curve-fitting. The results for one experiment are shown, whereas results from two other tests producing similar results are not shown.

$$
\text { http://www.endocrineconnections.org }
$$$$
\text { DOI: 10.1530/EC-17-0067 }
$$

follitropin alfa and $0.299 \mathrm{nM}$ for follitropin delta, with the results from a representative experiment shown in Fig. 1, resulting in a calculated $K_{\mathrm{i}}$ of approximately $0.1 \mathrm{nM}$ for both proteins.

\section{In vitro bioactivity using a HEK-293 cell line expressing the human FSH receptor}

To compare the in vitro bioactivity of follitropin delta and follitropin alfa, both rFSH proteins were incubated in vitro with human embryonic kidney cells (HEK-293 cells) engineered to stably express the human FSH receptor, measuring production of the second messenger cAMP. The potency of the two rFSH proteins was virtually identical in this assay (Fig. 2), with follitropin alfa activating the hFSH receptor with an $\mathrm{EC}_{50}$ of $0.0174 \mathrm{nM}$, and follitropin delta producing an $\mathrm{EC}_{50}$ of $0.0171 \mathrm{nM}$. In a second independent experiment, follitropin alfa produced an $\mathrm{EC}_{50}$ of $0.0182 \mathrm{nM}$ and follitropin delta produced an $\mathrm{EC}_{50}$ of $0.0181 \mathrm{nM}$ (data not shown).

\section{In vitro bioactivity using fresh luteinized granulosa cells from IVF patients}

The in vitro bioactivity of follitropin delta and follitropin alfa was then compared using luteinized granulosa cells isolated from follicles of IVF patients and expressing the endogenous human FSH receptor. These experiments examined the impact of rFSH proteins on granulosa cell production of estradiol, progesterone, inhibin A and

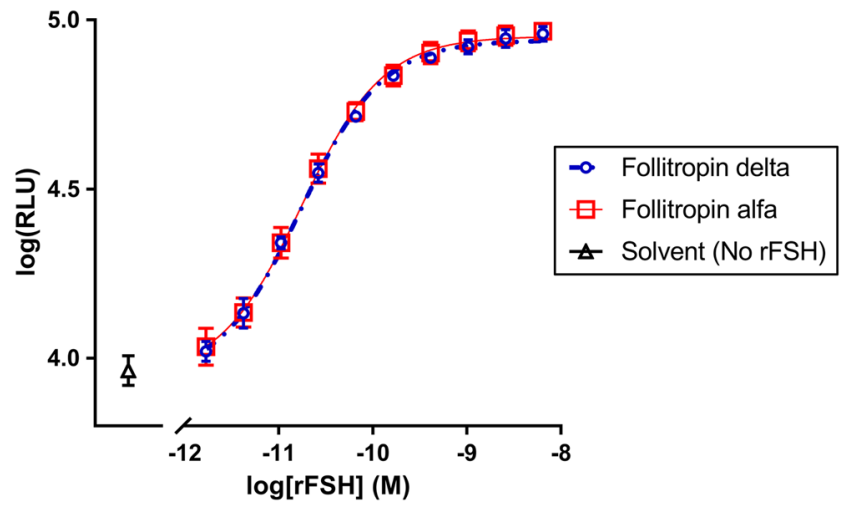

Figure 2

Production of cAMP in response to activation of the human FSH receptor in stably transfected HEK-293 cells was measured across the indicated concentrations of follitropin delta (open circles, blue), follitropin alfa (open squares, red) or no recombinant FSH (open triangles, black) with increasing luminescence (RLU) proportional to increasing cAMP present. Each concentration of $\mathrm{rFSH}$ proteins was tested in quadruplicate, with the mean and S.D. shown.

This work is licensed under a Creative Commons Attribution 4.0 International License. 
inhibin $B$, and on the expression of genes including CYP19a1, 3B-HSD and Inh A. Granulosa cells were collected following triggering of final follicle maturation at oocyte pickup from a total of 13 women undergoing controlled ovarian stimulation prior to IVF. Both rFSH proteins induced progesterone production approximately $300 \%$ normalized to basal levels in the absence of $\mathrm{rFSH}$ $(P>0.1)$, and with similar potency (Fig. 3A). Inhibin $A$ in supernatant was increased by both $\mathrm{rFSH}$ proteins approximately 35-40\% over basal (Fig. 3B), while estrogen and inhibin $\mathrm{B}$ were not significantly increased by either rFSH protein (data not shown). The expression of FSH regulated genes was studied in the same human granulosa
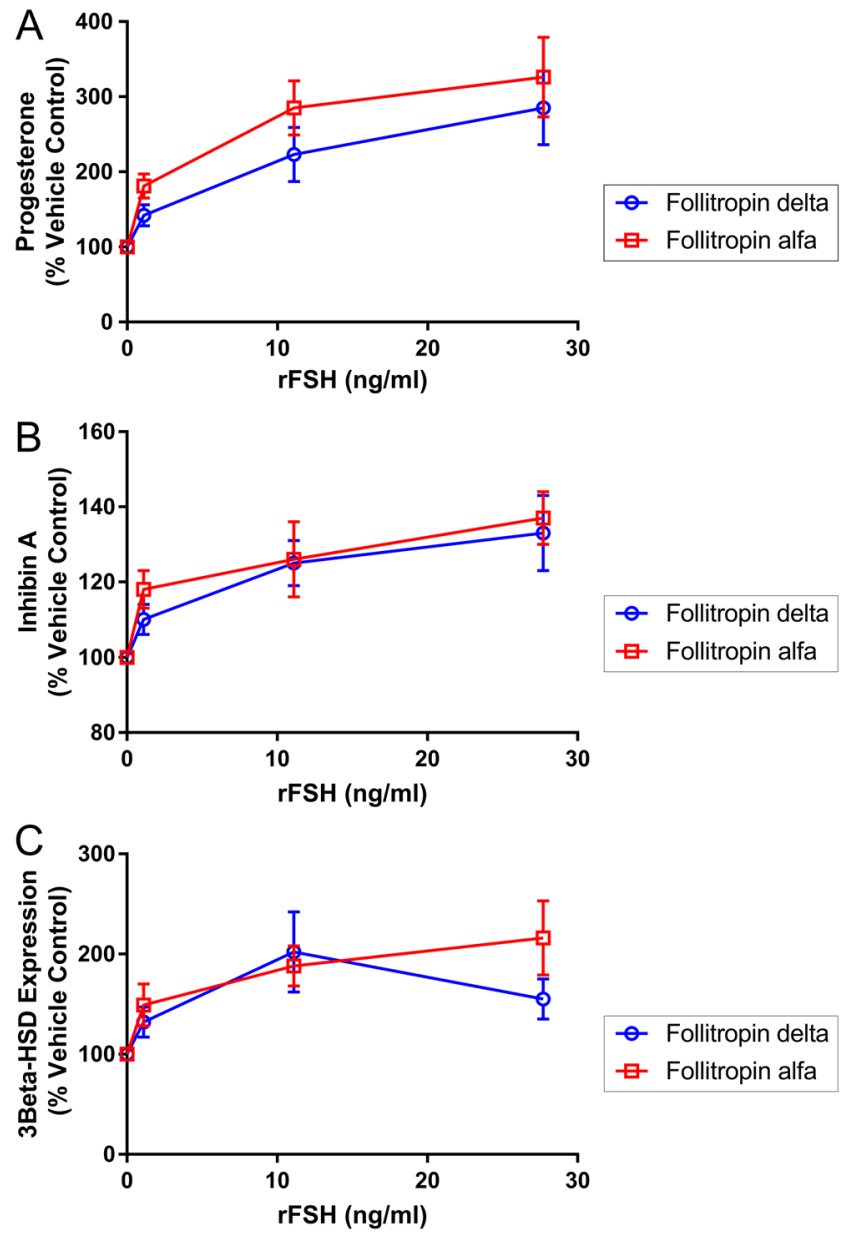

\section{Figure 3}

The induction of hormone release and increase in gene expression were measured in human granulosa cells exposed to rFSH proteins in vitro. Cells from eight patients were included, with duplicate samples of cells from each patient tested at each rFSH concentration, normalizing responses relative to the level observed in the absence of $\mathrm{rFSH}(100 \%)$, with data points reflecting the mean and S.E.M. The response for follitropin delta (open circles, blue) and follitropin alfa (open squares, red) is shown in terms of progesterone secretion (A), inhibin A secretion (B) and 3beta-HSD gene expression (C).

$$
\begin{aligned}
& \text { http://www.endocrineconnections.org } \\
& \text { DOI: 10.1530/EC-17-0067 }
\end{aligned}
$$

cell studies, preparing RNA at the end of the incubation period to be quantitated. Expression of $3 B-H S D$ was induced approximately $200 \%$ by both rFSH proteins (Fig. 3C), the CYP19a1 gene was induced $40-50 \%$ by both rFSH proteins (data not shown) and INHA expression was induced by both rFSH proteins $50-100 \%$ over basal levels (data not shown).

\section{Steelman-Pohley assay}

The Steelman-Pohley bioassay concept was used to demonstrate the bioactivity of follitropin delta in rat compared to an international reference standard of recombinant FSH produced in CHO cells. When follitropin delta and follitropin alfa were compared by SteelmanPohley assay based on dosing of a previously assessed bioactivity, the two compounds produce parallel curves and, thus, are very similar in their pharmacodynamic behavior in rat (Fig. 4).

\section{Specialized rat pharmacokinetics (ASF competition)}

To examine the role of the ASPGR in clearance of follitropin delta and follitropin alfa, the rFSH proteins were injected intravenously in rats in the presence or absence of a saturating dose of asialofetuin (ASF), a ligand for the ASGPR that can compete and block the hepatic clearance of other ASGPR ligands. Co-injection of a saturating dose of ASF reduced the clearance of follitropin delta from serum, resulting in a $42 \%$ increase in the AUC compared to the absence of ASF (Fig. 5) and a significant difference in ASF level in plasma at one hour while co-injection with ASF did not significantly affect follitropin alfa clearance or plasma levels.

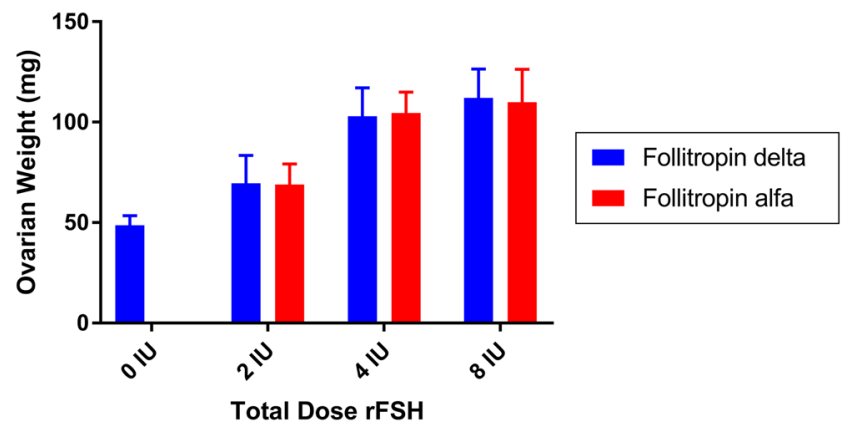

Figure 4

The bioactivity of follitropin delta (blue bars) and follitropin alfa (red bars) was compared in vivo in rat in the Steelman-Pohley bioassay, measuring the increase in ovarian weight with the administration of the indicated total dose of rFSH proteins. Bars are the mean of 14 animals in each dose group, and error bars are the s.D.

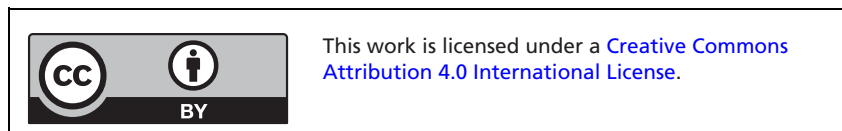




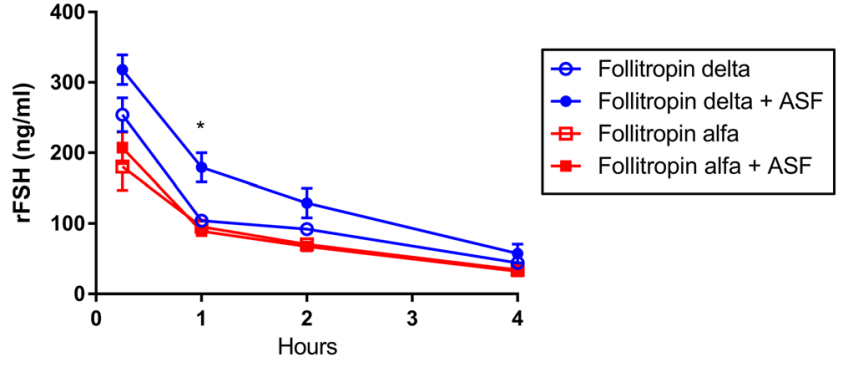

Figure 5

The clearance of follitropin delta (blue circles) and follitropin alfa (red squares) was compared following intravenous injection in rat, in the presence of a saturating dose of ASF (filled symbols), or the absence of co-injected ASF (open symbols). Serum taken at the indicated time points was analyzed for rFSH concentration. A Student's $t$-test compared results in the presence or absence of ASF, with an asterisk (*) indicating a significant difference $(P<0.05)$.

\section{Specialized mouse pharmacokinetics (Asgpr knockout model)}

To further examine the role of ASGPR in clearance of follitropin alfa and follitropin delta, their pharmacokinetics were compared in wild-type and ASGPR knockout mice, injecting identical volumes and concentrations of protein subcutaneously (Fig. 6). Follitropin alfa and follitropin delta displayed similar pharmacokinetic profiles following subcutaneous injection in wild-type mice. In ASGPR deficient mice, however, follitropin delta clearance from serum was reduced, and the AUC in serum following follitropin delta injection increased $40 \%$ compared to follitropin alfa, with a significant difference in plasma concentrations at the six- and nine-hour time points, further supporting the hypothesis that follitropin delta clearance from serum involves the ASGPR while follitropin alfa clearance relies less on this mechanism.

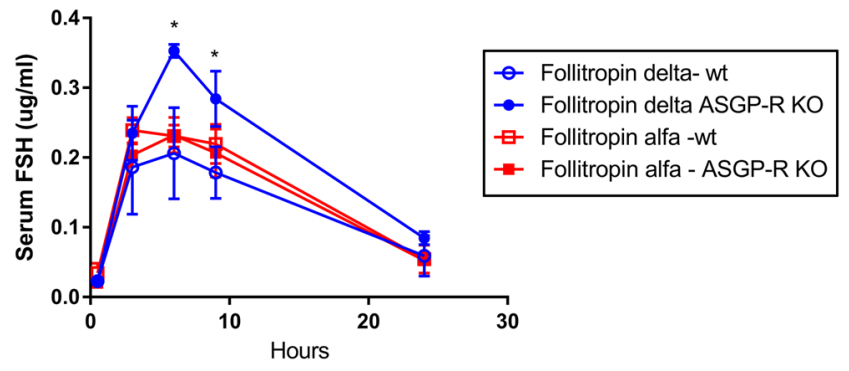

\section{Figure 6}

The clearance of follitropin delta (blue circles) and follitropin alfa (red squares) was compared in wild-type mice (open symbols) and Asgpr knockout mice (filled symbols), determining rFSH concentration present in serum at varying time points. A Student's $t$-test compared results in the presence or absence of ASF, with an asterisk (*) indicating a significant difference $(P<0.05)$

\section{Discussion}

Follitropin delta and follitropin alfa display distinct pharmacokinetic and pharmacodynamic properties in healthy female volunteers, with follitropin delta displaying lower clearance from serum, producing greater exposure and a greater pharmacodynamic response (13). In addition, follitropin delta displays a noninferior pregnancy rate and live birth rate compared to follitropin alfa, with a reduced rate of complications such as OHSS (39). The differences observed clinically between the two $\mathrm{rFSH}$ proteins might be caused by differences in their glycosylation (14) since variations in glycosylation have been reported to affect FSH pharmacokinetics and pharmacodynamics $(15,16$, $17,18,19)$. To better understand the clinical differences observed between the two rFSH proteins, we compared their signaling through the human FSH receptor and their pharmacokinetics in rodents.

When compared directly it was found that follitropin delta and follitropin alfa elicit indistinguishable activity at the human FSH receptor in vitro. The two $\mathrm{rFSH}$ proteins displayed the same apparent binding affinity for the human FSH receptor, and virtually identical potency in the activation of the human FSH receptor in a HEK293 cell-based assay, measuring the induction of cAMP production in response to agonist ligand. Differences in the clinical activity of the two rFSH proteins are unlikely to be caused by differences in their binding and activation of the FSH receptor.

Further comparing the two rFSH proteins, they produced similar in vitro responses in patient-derived luteinized granulosa cells, measuring FSH-induced hormone production and gene regulation. In addition to inducing progesterone production to similar levels, both $\mathrm{rFSH}$ proteins increased $3 B-H S D$ expression, the enzyme responsible for the conversion of pregnenolone to progesterone (26). The modest induction of CYP19a1 gene expression by both $\mathrm{rFSH}$ proteins is consistent with previous reports in granulosa cells $(27,28,29)$ as was the induction of both INHA gene expression and inhibin A protein secretion (30). The lack of increase in estrogen and inhibin B in these studies is consistent with the stage at which the granulosa cells were collected, after patients had been through controlled ovarian stimulation and triggering of final oocyte maturation, shifting them from follicular gene expression and hormone production toward luteal phase gene expression (31). Also, the absence of a source of steroidal precursors for estrogen biosynthesis in this in vitro system prevented significant estrogen production (32).

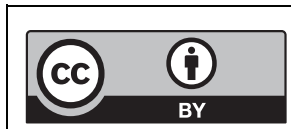

This work is licensed under a Creative Commons Attribution 4.0 International License. 
The differences in follitropin delta and follitropin alfa responses in rats and in women may be due in part to differences in pharmacokinetics, including clearance. A potential mechanism of $\mathrm{rFSH}$ clearance from serum is by hepatic asialoglycoprotein receptor (ASGPR), which mediates the rapid clearance from serum of glycoproteins containing terminal galactose, GalNac or alpha2,6 sialic acid, and GalNac with 2.6 sialic acid, the latter having a high affinity for the rat ASGPR $(33,34)$.

Inhibition of ASGPR-dependent clearance in rats by co-injection of a saturating dose of ASF (35) reduced clearance of follitropin delta from serum but did not affect follitropin alfa clearance. Similarly, the clearance of follitropin delta was reduced in Asgpr knockout mice compared to wild-type mice, further supporting the role of the hepatic ASGPR in clearance of follitropin delta but not follitropin alfa from serum. This difference in rFSH clearance from serum by the liver is likely to result in differing metabolic fates for the two $\mathrm{rFSH}$ proteins.

Other factors might also play a role in the distinct pharmacokinetics of follitropin delta. Human expression of hepatic ASGPR is lower than in mouse or rodent, suggesting less dependence on this clearance mechanism in humans (36). Renal clearance also plays a role in FSH pharmacokinetics, and the greater sialic acid content of follitropin delta compared to follitropin alfa, with increased charge and size, is likely to result in lower renal clearance $(37,38)$ as well as impacting hepatic clearance.

The distinct properties of follitropin delta have important implications for its pharmacology and clinical use. The Steelman-Pohley assay for the determination of FSH bioactivity utilizes a recombinant reference standard (1st IS FSH, recombinant 92/642) expressed in CHO cells. As a result, bioactivity in the Steelman-Pohley assay compared to the reference standard does not directly predict the pharmacodynamic response of follitropin delta in humans, as was observed. Dosing follitropin delta according to mass rather than bioactivity measured in rat is important as a result. This principle is being pursued in follitropin delta clinical development, with individualized dosing by mass optimized for each patient based on their AMH level and weight $(11,12)$. The differences between the pharmacology of follitropin delta and follitropin alfa also suggest that one should not be directly substituted for the other in one clinical procedure. Future innovation in the treatment of infertility should continue to consider the impact of the unique properties of $\mathrm{rFSH}$ proteins on their therapeutic use.

\section{Declaration of interest}

Glenn Croston was paid as a consultant by Ferring Pharmaceuticals. Daniel Plaksin is an employee of BTG Israel, a subsidiary of Ferring Pharmaceuticals. Claus Yding Andersen, Janni $V$ Jeppesen and Kirsten $T$ Macklon received funding from Ferring Pharmaceuticals. Wolfgang Koechling is an employee of Ferring Pharmaceuticals A/S.

\section{Funding}

This research was funded by Ferring Pharmaceuticals and its subsidiaries.

\section{References}

1 Howles CM. Role of LH and FSH in ovarian function. Molecular and Cellular Endocrinology 2000161 25-30. (doi:10.1016/S03037207(99)00219-1)

2 Macklon NS, Stouffer RL, Giudice LC \& Fauser BC. The science behind 25 years of ovarian stimulation for in vitro fertilization. Endocrine Reviews 200627 170-207. (doi:10.1210/er.2005-0015)

3 Tarlatzis BC, Fauser BC, Kolibianakis EM, Diedrich K, Rombauts L \& Devroey P. GnRH antagonists in ovarian stimulation for IVF. Human Reproduction Update 200612 333-340. (doi:10.1093/humupd/dml001)

4 Howles CM. Genetic engineering of human FSH (Gonal-F). Human Reproduction Update 19962 172-191. (doi:10.1093/humupd/2.2.172)

5 Goa KL \& Wagstaff AJ. Follitropin alpha in infertility: a review. BioDrugs 19989 235-260. (doi:10.2165/00063030-199809030-00006)

6 Out HJ, Mannaerts BM, Driessen SG \& Coelingh Bennink HJ. Recombinant follicle stimulating hormone (rFSH; Puregon) in assisted reproduction: more oocytes, more pregnancies. Results from five comparative studies. Human Reproduction Update 19962 162-171. (doi:10.1093/humupd/2.2.162)

7 Wang H, Chen X, Zhang X, Zhang W, Li Y, Yin H, Shao H \& Chen G. Comparative assessment of glycosylation of a recombinant human FSH and a highly purified FSH extracted from human urine. Journal of Proteome Research 201615 923-932. (doi:10.1021/acs. jproteome.5b00921)

8 Hård K, Mekking A, Damm JB, Kamerling JP, de Boer W, Wijnands RA \& Vliegenthart JF. Isolation and structure determination of the intact sialylated N-linked carbohydrate chains of recombinant human follitropin expressed in Chinese hamster ovary cells. European Journal of Biochemistry 1990193 263-271. (doi:10.1111/j.1432-1033.1990. tb19332.x)

9 Olijve W, de Boer W, Mulders JW \& van Wezenbeek PM. Molecular biology and biochemistry of human recombinant follicle stimulating hormone (Puregon). Molecular Human Reproduction 19962 371-382. (doi:10.1093/molehr/2.5.371)

10 World Intellectual Property Organization (WO 2013/020996 A1) Composition for controlled ovarian stimulation.

11 Arce JC, Andersen AN, Fernández-Sánchez M, Visnova H, Bosch E, García-Velasco JA, Barri P, de Sutter P, Klein BM \& Fauser BC. Ovarian response to recombinant human follicle-stimulating hormone: a randomized, antimüllerian hormone-stratified, dose-response trial in women undergoing in vitro fertilization/intracytoplasmic sperm injection. Fertility and Sterility 2014102 1633-1640. (doi:10.1016/j. fertnstert.2014.08.013)

12 Bosch E, Nyboe Andersen A, Barri P, García-Velasco JA, de Sutter P, Fernández-Sánchez M, Visnova H, Klein BM, Mannaerts B \& Arce JC. Follicular and endocrine dose responses according to antiMüllerian hormone levels in IVF patients treated with a novel human recombinant FSH (FE 999049). Clinical Endocrinology 201583 902-912. (doi:10.1111/cen.12864)

13 Olsson H, Sandstrom R \& Grundemar L. Different pharmacokinetic and pharmacodynamic properties of recombinant follicle-stimulating hormone (rFSH) derived from a human cell line compared with rFSH

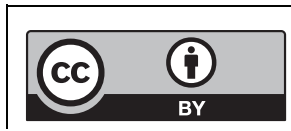

This work is licensed under a Creative Commons Attribution 4.0 International License. 
from a non-human cell line. Journal of Clinical Pharmacology 201454 1299-1307. (doi:10.1002/jcph.328)

14 World Intellectual Property Organization (WO 2009/127826 A1) Recombinant FSH including alpha 2,3 and alpha 2,6 sialylation.

15 Ulloa-Aguirre A, Damián-Matsumura P, Jiménez M, Zambrano E \& Díaz-Sánchez V. Biological characterization of the naturally occurring analogues of intrapituitary human follicle-stimulating hormone. Human Reproduction 19927 23-30. (doi:10.1093/oxfordjournals. humrep.a137550)

16 de Leeuw R, Mulders J, Voortman G, Rombout F, Damm J \& Kloosterboer L. Structure-function relationship of recombinant follicle stimulating hormone (Puregon). Molecular Human Reproduction 19962 361-369. (doi:10.1093/molehr/2.5.361)

17 Timossi CM, Barrios-de-Tomasi J, González-Suárez R, Arranz MC, Padmanabhan V, Conn PM \& Ulloa-Aguirre A. Differential effects of the charge variants of human follicle-stimulating hormone. Journal of Endocrinology 2000165 193-205. (doi:10.1677/joe.0.1650193)

18 Creus S, Chaia Z, Pellizzari EH, Cigorraga SB, Ulloa-Aguirre A \& Campo S. Human FSH isoforms: carbohydrate complexity as determinant of in vitro bioactivity. Molecular and Cellular Endocrinology 2001174 41-49. (doi:10.1016/S0303-7207(00)00453-6)

19 Andersen CY \& Ezcurra D. What is the clinical relevance of folliclestimulating hormone isoforms in fertility treatment? Reproductive Biology Insights 20114 1-10. (doi:10.4137/RBI.S7362)

20 Cheng Y \& Prusoff WH. Relationship between the inhibition constant (Ki) and the concentration of inhibitor which causes 50 per cent inhibition (I50) of an enzymatic reaction. Biochemical Pharmacology 197322 3099-3108. (doi:10.1016/0006-2952(73)90196-2)

21 Ryding J, Hjertberg E \& Rasmussen BB. Comparison of two direct neutralizing assay formats using recombinant follicle-stimulating hormone as agonist. Journal of Immunological Methods 2013 400-401 87-96. (doi:10.1016/j.jim.2013.10.008)

22 Borgbo T, Sommer Kristensen L, Lindgren I, Yding Andersen C \& Hansen LL. Genotyping common FSHR polymorphisms based on competitive amplification of differentially melting amplicons (CADMA). Journal of Assisted Reproduction and Genetics 201431 1427-1426. (doi:10.1007/s10815-014-0329-6)

23 Schmittgen TD \& Livak KJ. Analyzing real-time PCR data by the comparative CT method. Nature Protocols 20083 1101-1108. (doi:10.1038/nprot.2008.73)

24 Steelman SL \& Pohley FM. Assay of the follicle stimulating hormone based on the augmentation with human chorionic gonadotrophin. Endocrinology 195353 604-614. (doi:10.1210/endo-53-6-604)

25 Ishibashi S, Hammer RE \& Herz J. Asialoglycoprotein receptor deficiency in mice lacking the minor receptor subunit. Journal of Biological Chemistry 1994269 27803-27806.

26 Sasson R, Rimon E, Dantes A, Cohen T, Shinder V, Land-Bracha A \& Amsterdam A. Gonadotrophin-induced gene regulation in human granulosa cells obtained from IVF patients. Modulation of steroidogenic genes, cytoskeletal genes and genes coding for apoptotic signaling and protein kinases. Molecular Human Reproduction 200410 299-311. (doi:10.1093/molehr/gah041)

27 Rimon E, Sasson R, Dantes A, Land-Bracha A \& Amsterdam A. Gonadotropin-induced gene regulation in human granulosa cells obtained from IVF patients: modulation of genes coding for growth factors and their receptors and genes involved in cancer and other diseases. International Journal of Oncology 200424 1325-1338. (doi:10.3892/ijo.24.5.1325)

28 Lindeberg M, Carlström K, Ritvos O \& Hovatta O. Gonadotrophin stimulation of non-luteinized granulosa cells increases steroid production and the expression of enzymes involved in estrogen and progesterone synthesis. Human Reproduction 200722 401-406. (doi:10.1093/humrep/del408)

29 Ophir L, Yung Y, Maman E, Rubinstein N, Yerushalmi GM, Haas J, Barzilay E \& Hourvitz A. Establishment and validation of a model for non-luteinized human mural granulosa cell culture. Molecular and Cellular Endocrinology 2014384 165-174. (doi:10.1016/j. mce.2014.01.018

30 Loreti N, Ambao V, Andreone L, Trigo R, Bussmann U \& Campo S. Effect of sialylation and complexity of FSH oligosaccharides on inhibin production by granulosa cells. Reproduction $2013 \mathbf{1 4 5}$ 127-135. (doi:10.1530/REP-12-0228)

31 Andersen CY \& Byskov AG. Estradiol and regulation of anti-Mullerian hormone, inhibin-A and inhibin-B secretion: analysis of small antral and preovulatory human follicles' fluid. Journal of Clinical Endocrinology and Metabolism 200691 4064-4069. (doi:10.1210/jc.2006-1066)

32 Erickson GF, Magofflin DA, Dyer CA \& Hofeditz C. The ovarian androgen producing cells: a review of structure/function relationships. Endocrine Reviews 19856 371-399. (doi:10.1210/edrv-63-371)

33 Park EI, Manzella SM \& Baenziger JU. Rapid clearance of sialylated glycoproteins by the asialoglycoprotein receptor. Journal of Biological Chemistry 2003278 4597-4602. (doi:10.1074/jbc.M210612200)

34 Steirer LM, Park EI, Townsend RR \& Baenziger JU. The asialoglycoprotein receptor regulates levels of plasma glycoproteins terminating with sialic acid alpha2,6-galactose. Journal of Biological Chemistry 2009284 3777-3783. (doi:10.1074/ jbc.M808689200)

35 Rotundo RF, Rebres RA, Mckeown-Longo PJ, Blumenstock FA \& Saba TM. Circulating cellular fibronectin may be a natural ligand for the hepatic asialoglycoprotein receptor: possible pathway for fibronectin deposition and turnover in the rat liver. Hepatology 199828 475-485. (doi:10.1002/hep.510280227)

36 Poulin P. A single-species approach considering additional physiological information for prediction of hepatic clearance of glycoprotein derivate therapeutics. Clinical Pharmacokinetics 201150 665-674. (doi:10.2165/11592610-000000000-00000)

37 Emmanouel DS, Stavropoulos T \& Katz AI. Role of the kidney in metabolism of gonadotropins in rats. American Journal of Physiology 1984247 E786-E792.

38 Perlman S, van den Hazel B, Christiansen J, Gram-Nielsen S, Jeppesen CB, Andersen KV, Halkier T, Okkels S \& Schambye HT. Glycosylation of an N-terminal extension prolongs the half-life and increases the in vivo activity of follicle stimulating hormone. Journal of Clinical Endocrinology and Metabolism 200388 3227-3235. (doi:10.1210/ jc.2002-021201)

39 Nyboe Andersen A, Nelson SM, Fauser BCJ, Garcia-Velasco JA, Klein BM, Arce JC \& ESTHER-1 Study Group. Individualized versus conventional ovarian stimulation for in vitro fertilization a multicenter, randomized, controlled, assessor-blinded, phase 3 noninferiority trial. Fertility and Sterility $2017 \mathbf{1 0 7} 387-396$. (doi:10.1016/j.fertnstert.2016.10.033)
Received in final form 25 April 2017

Accepted 27 April 2017

Accepted Preprint published online 27 April 2017 http://www.endocrineconnections.org DOI: 10.1530/EC-17-0067 (c) 2017 The authors Published by Bioscientifica Ltd

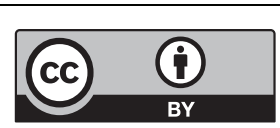

This work is licensed under a Creative Commons Attribution 4.0 International License. 